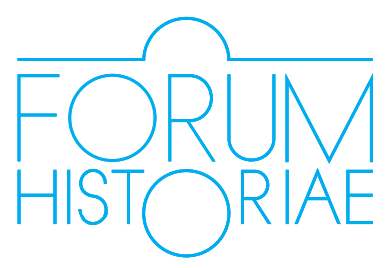

\title{
Medieval Dynasties in Medieval Studies: A Historiographic Contribution*
}

\author{
Dušan Zupka
}

\begin{abstract}
ZUPKA, Dušan: Medieval Dynasties in Medieval Studies: A Historiographic Contribution.

The article provides an overview of the current research on the notion, idea and perception of dynasties in medieval Europe. It deals with a variety of studies and books that focus on dynasty and dynastic historical writing within Central Europe, as well as outside this region. The main goal is to provide a selection of examples of how the notion of dynasty can be used in current historiographic discourse. First and foremost, dynasty in medieval studies seems to be (to a certain extent) another intellectual construct applied to the period in question. Just like any other similar concepts, like medieval, feudalism, ritual, community, etc., it helps historians to describe our modern understanding of the phenomena. As a result, dynasty has become a highly fashionable term and a popular recurring theme used in the historiography of the Middle Ages. Medieval dynasties are defined based on family, kinship and shared tradition. In fact, they should not be seen only as a biological line of relatives, but, even more importantly, as a political construct. Last, but by no means least, dynasty should always be scrutinized in connection with genealogy, idoneity and legitimacy.
\end{abstract}

Keywords: medieval studies, dynasty, historiography, dynastic history, Central Europe, ruling power, genealogy

DOI: https://doi.org/10.31577/forhist.2019.13.2.6

This was the period in which the Welfs identified themselves as Welfs.

(Leah Shopkow, Dynastic Historical Writing, p. 228)

\section{Introduction}

$\mathrm{T}$ The concept of dynasty in medieval studies is perceived as a given. Current research within Central Europe, as well as outside this region, provides abundant examples of how the notion of dynasty can be used. Historians usually speak about dynastic identity, dynastic consciousness, dynastic rulership, or even dynastic historical thought. ${ }^{1}$

\footnotetext{
* The research for this study was sponsored by research grants APVV-15-0349 Indivíduum a spoločnost' ich vzájomná reflexia v historickom procese [The Individual and the Society: Their Mutual Reflections in the Historical Process] and KEGA 004UKF-4/2018 Európsky stredovek interaktívne [The European Middle Ages, Interactively]. The final version of this paper is a result of the author's research carried out in $2015-2016$ within the framework of ERC Starting grant project Jagiellonians: Dynasty, Memory and Identity in Central Europe.

1 ANDENNA, Cristina - MELVILLE, Gert. Idoneität - Genealogie - Legitimation : Begründung und Akzeptanz von dynastischer Herrschaft im Mittelalter. Köln ; Weimar ; Wien : Böhlau, 2015; VERCAMER, Grischa WÓŁKIEWICZ, Ewa (eds.) Legitimation von Fürstendynastien in Polen und dem Reich : Identitätsbildung im Spiegel schriftlicher Quellen (12. - 15. Jahrhundert). Wiesbaden : Harrasowitz, 2016; CLASSEN, Albrecht. Handbook of Medieval Culture : Fundamental Aspects and Conditions of the European Middle Ages. Berlin : De Gruyter, 2015; ROSENWEIN, Barbara H. A Short History of the Middle Ages. Peterborough, Ont. ; Ormskirk : Broadview, 2002; VOCELKA, Karl. Die Lebenswelt der Habsburger : Kultur-und Mentalitätsgeschichte einer
} 
A variety of studies and books focus on the notion, idea and perception of dynasties in medieval Europe, from which one can conclude several general observations. First and foremost, dynasty in medieval studies seems to be (to a certain extent) another intellectual construct applied for the period in question. Just like any other similar concept, like medieval, feudalism, ritual, community, etc., it helps historians to describe our modern understanding of the phenomena. Everyone is talking about it, but no one seems to be worried about its definition, meaning, evolution, methodological framework and so on. The vast majority of the works on medieval dynasties use the notion without providing a definition of it.

Numerous examples of famous medieval dynasties from the Latin West (Carolingian, Ottonian, Salian, Angevin), Byzantium (Komnenian, Macedonian), Central European region (Arpadian, Přemyslid, Piast), Eastern Orthodox sphere (Rurikids), and even the Muslim world (Fatimid, Umayyad, Osman) can be repeatedly found in current scholarship.

The great importance of dynasties in current discourse in medieval studies is reflected in their application for chronologic purposes. Periods of national, regional or royal histories are set within the framework of dynasties. In this respect, historians usually talk about the Carolingian period, the Jagiellonian era, Ottonian Germany, Komnenian Byzantium, the Umayyad Caliphate, Rurikid Rus' etc. The reign of a certain dynasty is thus perceived as a relevant delineator of historical periods and epochs. Another striking feature of the appropriation of the concept of dynasties in contemporary medieval studies is that dynasty conflates (substitutes) numerous related terms like family, kinship, lineage, genealogy, ruling house, royal house, ruling family, etc. ${ }^{2}$ As a result, dynasty became a highly fashionable term and one of the popular recurring themes used in the historiography of the Middle Ages.

\footnotetext{
Familie. Graz : Styria, 1997; WEBER, Wolfgang E. J. “Dynastiesicherung and Staatsbildung. Die Entfaltung des frühmodernen Fürstenstaates." In WEBER, Wolfgang E. J. (ed.) Der Fürst. Ideen und Wirklichkeiten in der europäischen Geschichte. Cologne : Böhlau, 1998, p. 95: "Sowohl die Entstehung einer Dynastie als auch deren Verfestigung sind deshalb wesentlich als Ergebnis bewußter Handelns aufzufassen, welchem entsprechend typische Elemente und Muster zugeschrieben werden können".

2 MOEGLIN, Jean-Marie. Les dynasties princières allemandes et la notion de Maison à la fin du Moyen Age. In Éditions de la Sorbonne (ed.) Les princes et le pouvoir au Moyen Age. Paris : Éditions de la Sorbonne, 1993, pp. 137-154; MOEGLIN, Jean-Marie. Zur Entwicklung dynastischen Bewusstseins der Fürsten im Reich vom 13. zum 15. Jahrhundert. In SCHNEIDMÜLLER, Bernd (ed.) Die Welfen und Ihr Braunschweiger Hof im Hohen Mittelalter. Wiesbaden : Harrassowitz Verlag, 1995, pp. 523-540; JOHANEK, Peter. "Die Schreiber und die Vergangenheit. Zur Entfaltung einer dynastischen Geschichtsschreibung an den Fürstenhöfen des 15. Jahrhunderts.” In KELLER, Hagen et al. (eds.) Pragmatische Schriftlichkeit im Mittelalter : Erscheinungsformen und Entwicklungsstufen. Munich : Wilhelm Fink Verlag, 1992, pp. 195-209; KLAPISCH-ZUBER, Christiane. The Genesis of the Family Tree, In I Tatti. Studies in the Italian Renaissance, 1991, Vol. 4, pp. 105-129; HECHBERGER, Florian. Staufer \& Welfen : Zwei Rivalisierende Dynastien Im Hochmittelalter. Regensburg : Pustet, 2009; SEMMLER, Josef. Der Dynastiewechsel von 751 und die fränkische Königssalbung. Düsseldorf : Droste Verlag, 2003; HLAWITSCHKA, Eduard. Stirps regia. Forschungen zu Königtum und Führungsschichten im früheren Mittelalter. Ausgewählte Aufsätze. Festgabe zum seinem 60. Geburtstag. Frankfurt am Main : Peter Lang, 1988; EALES, Richard G. - TYAS, Shaun. Family and Dynasty in Late Medieval England. Donington : Paul Watkins, 2003; SUTTER FICHTNER, Paula. The Habsburgs : Dynasty, Culture and Politics. London : Reaktion, 2014.
} 


\title{
II. The Concept and Definition of Dynasty in Medieval Studies
}

\author{
General reference books often used by scholars of medieval studies do not treat \\ dynasty as a subject worth of separate consideration. ${ }^{3}$ From a wide range of pub- \\ lications of recent medieval studies, one can draw the outline of the main ideas \\ and approaches: the treatment of dynasty in connection especially to lineage, ge- \\ nealogy, family, kinship, identity, history, and historiography. ${ }^{4}$
}

The influential German medievalist Karl Schmid worked on the notions of family, kinship, lineage, house and dynasty (Familie, Sippe, Geschlecht, Haus und Dynastie), studying in detail the recurrent terms like patruus, nepos, consanguineus, consobrinus, translatio sanguinis, stirps, königliche Familie, Königshaus, Königsherrschaft, Haus, Adelshaus, Hausherrschaft, Hauspolitik, but he strikingly avoided dynasty. ${ }^{5}$ When assessing the Adelsgeschlecht, he apparently does not see it as a genealogical relation of families in the form of agnatio. He concludes that lineages were historical communities which had their own history according to the law of growth and decay - this enabled the emergence of new linages and families and, therefore, the extinction of the male lineage was not such a devastating issue as shown by the Welfs. The self-consciousness of a lineage consisted of its tradition, honour, descent, kinship, name, symbols, social position, richness, power etc. Not the genealogy in biological sense, but much more the self-consciousness in its own tradition, lent a historicity to the lineage (Geschichtlichkeit). ${ }^{6}$

3 In the Lexikon des Mittelalters, dynasty does not appear as a headword, although it discusses the Carolingians as a Frankish dynasty, Pepin III as "Begründer der zweiten frk. Dynastie", and the Dynastie der Jagiellonen. Separate contributions deal with the Arpadian, the Piast and the Prremyslid dynasties etc. Lexikon des Mittelalters. Munich ; Zürich : Verlag J. B. Metzler, Vol. 5, cols. 275-276; 935-937. The Encyclopedia of the Middle Ages. VAUCHEZ, André (ed.). Cambridge : Routledge, 2000, provides 3,000 concise and detailed articles on all aspects of the period from the fifth to the fifteenth century, but not about dynasty. In a detailed manner, the editors described that the Carolingian family left its direct mark on history from the early 7 th c. until 987. In a first stage, it had acquired the political responsibilities that gradually made it a princely dynasty. With Pippin the Short, in 751, it acceded to royalty, and in 800 Charlemagne became emperor. These successive titles both supposed and founded a dynastic legitimacy. It was not the extinction of the family that led to the final setting aside of the Carolingians. In 987, the uncle of Louis V was capable of reigning and had sons to succeed him. It was rather a progressive loss of the substance that formed the basis of this capacity to reign, what we term "legitimacy", a term that is ultimately hard to define (Claude Carozzi). The Oxford Dictionary of the Middle Ages. BJORK, Robert (ed.). Oxford : Oxford University Press, 2010, claims to be an essential new reference work covering all key aspects of European history, society, and culture from 500 to $1500 \mathrm{~A}$. D., as well as the Byzantine Empire, Islamic dynasties, and Asiatic peoples of the era. It does not define dynasty, but, for example, it deals with dynamics, or St. Dymphna; Il Medioevo : Barbari, cristiani, musulmani. ECO, Umberto (ed.). Roma : Encyclomedia, 2010, includes chapters as dinastia sassone e lo Sacro Romano Impero; L' impero Bizantino et la dinastia macedone, Constantino e la sua dinastia; dinastia teodosiana; la dinastia omayyade. Last but not least, Dictionnaire raisonné de l'Occident medieval. LE GOFF, Jacques Le Goff - SCHMITT, JeanClaude (eds.). Paris : Fayard, 1999 as well as the Handbook of Medieval Studies : Terms - Methods - Trends. CLASSEN, Albrecht (ed.). Berlin ; New York : De Gruyter, 2010, did not include dynasty as a separate entry. All in all, the definition generally accepted by scholars, and the one adopted in this article, is provided by the Oxford English Dictionary: dynasty; A succession of rulers of the same line or family; a line of kings or princes.

4 Rosamond McKitterick argued that the Carolingians invented annals to promote the status and ambitions of their dynasty. McKITTERICK, Rosamond. History and Memory in Carolingian Europe. Cambridge : Cambridge University Press, 2007, pp. 97-119.

5 SCHMID, Karl.Zur Problematik von Familie, Sippe und Geschlecht, Haus und Dynastie beim mittelalterlichen Adel. In Zeitschrift für die Geschichte des Oberrheins, 1957, Vol. 105, pp. 1-62.

6 SCHMID 1957, p. 57. Cf. Also: SCHMID, Karl. Geblüt - Herrschaft - Geschlechterbewußtsein. Grundfragen zum Verständnis des Adels im Mittelalter. Sigmaringen : Jan Thorbecke Verlag, 1998. 


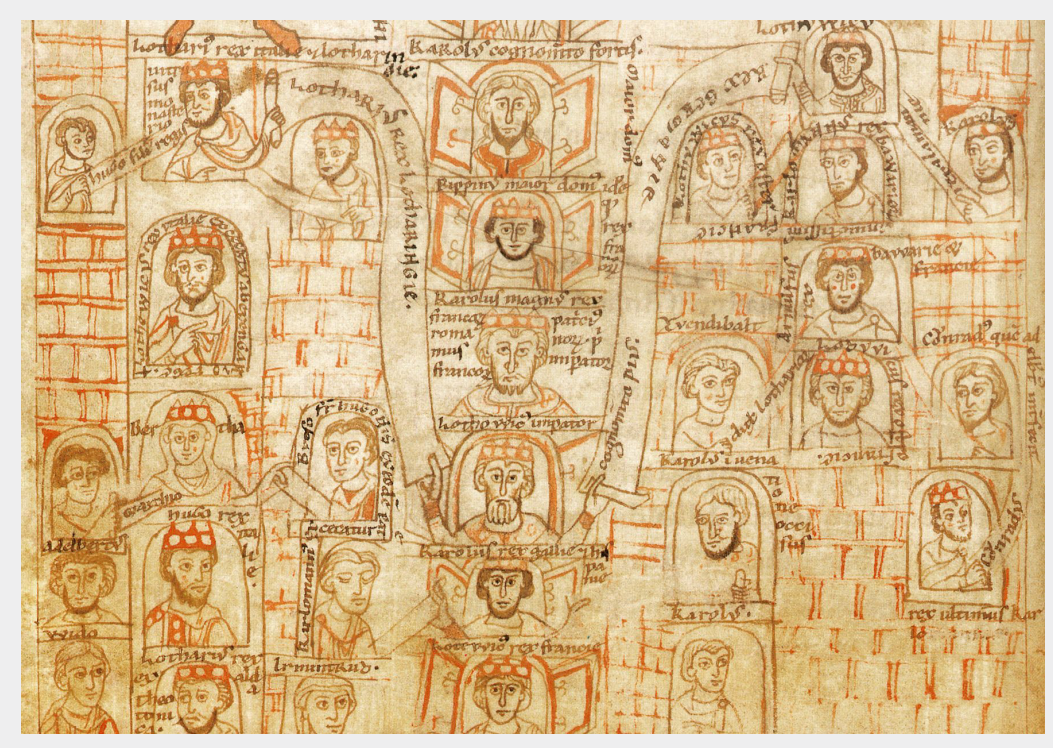

Figure 1: 12th-century family tree of the Carolingians. Staatsbibliothek zu Berlin Ms. lat. fol. $29580 v$.

Beate Kellner ${ }^{7}$ proposed the idea of genealogical awareness (genealogisches Wissen) stating that genealogic thinking in the Middle Ages was one of the earliest attempts to create a learning system and one of the earliest forms of understanding the world, and that genealogy was a dominant mental structure. Family and kinship were seen as the most important form of medieval people's consociation. The most striking examples of this thinking can be found in Petrus Pictaviensis' Compendium historiae in genealogia Christi (1130 - 1205), which served as a model for genealogical textbooks. Among the most influential points of references to dynasties, she quotes the Bible, Troy, Rome, and Melusine. Genealogical thinking and its use in medieval historical narrative was a topic of several inspiring papers written by Gabrielle Spiegel, too. ${ }^{8}$

Dynastic historical writing is a concept promoted by Charles West. ${ }^{9}$ In his work on medieval historiography, he states that the intersection of family and history-writing touches on two fundamental means by which all people situate themselves in their world: through kinship and in relation to the past. Combining family loyalties with past sensitivities, dynastic historical writing represents the creation of a special, and specially revealing, form of knowledge, caught between the socially embedded and the detached. He claims the emergence of a fully-fledged dynastic historiography to be a development of the tenth century which blossomed in the eleventh and twelfth, and maintained its presence, though in absolute terms becoming increasingly peripheral, right through the Later Middle Ages.

7 KELLNER, Beate. Ursprung und Kontinuität. Studien zum genealogischen Wissen im Mittelalter. München : Wilhelm Fink Verlag, 2004.

8 SPIEGEL, Gabrielle. Genealogy : Form and Function in Medieval Historical Narrative. In History and Theory, 1983, Vol. 22, No. 1, pp. 43-53. "Genealogical histories are thus, from a structural point of view, narrative mimeses of the creation of life itself and as such acquire a genuinely paradigmatic character as imitations of the supernatural order upon which the social order of the human community is based", p. 52. Cf. BRANDT, Hartwin et al. Genealogisches Bewusstsein als Legitimation : Inter- und Intragenerationelle Auseinandersetzungen sowie die Bedeutung von Verwandtschaft bei Amtswechseln. Bamberg : University of Bamberg Press, 2010.

9 Next paragraph follows: WEST, Charles. Dynastic Historical Writing. In FOOT, Sarah - ROBINSON, Chase F. (eds.) The Oxford History of Historical Writing. Vol 2. 400 - 1000. Oxford : OUP, 2012, pp. 496-516. 
According to West, William of Jumièges's history offers a paradigmatic illustration of this mode. William's intention was to document a lineage, an easy task since all the dukes were related to one another, and his account was based on an early eleventh-century history of the Norman people written by Dudo of Saint-Quentin and reflected the emphatically dynastic nature of the eleventh-century Norman principality. He also mentions the thirteenth-century Grandes chroniques de France [The Great Chronicles of France]. ${ }^{10}$ His conclusion is that, in the Medieval West, genealogies often interpreted themselves as a form of dynastic historical writing. The West has adopted the definition of this subject proposed by Leah Shopkow as "dynastic historiography is that 'whose organisational principle is the reign of a sequence of rulers or the generations of a family ${ }^{\prime \prime} .{ }^{11}$ In the case of Byzantium, she claims that no dynastic history-writing developed in this region, and one can only find historiography organised by the reigns of rulers who merely happened sometimes to be related.

Shopkow traces the concept of dynastic history ${ }^{12}$ stating that, to compose history using family as the organizing principle seems so natural to historians that they have hardly questioned the appearance of histories so organised. In the High Middle Ages, the existence of dynastic histories, i.e. genealogies, family histories and regnal history organized around the lives of individuals, could be observed. Some scholars have argued that genealogical thinking was a fundamental mode of thought in the Middle Ages, with the Bible, describing all humanity descending from Adam, having preconditioned this genealogical thinking. She notices that more of this kind of histories were written around 950 and they treated families below the level of royalty. Shopkow briefly outlines a variety of other views, for example that of Georges Duby, who wrote that the appearance of narrative histories organized around the family in the mid-10th century grew from a cultural change in the elite themselves - around $1000 \mathrm{AD}$, they began to identify themselves as members of a lineage, descended from a common ancestor, as well as holders of a particular patrimony. ${ }^{13}$ An alternative view was proposed by Patrick Geary, who sees the reason in the loss of knowledge by the elite of their ancestors - Carolingian holdings scattered far away from the monasteries which kept the family memory (libri memoriales) resulted in the families being forced to secure their memories by creating dynastic histories. ${ }^{14}$

In her account, Shopkow traces several influential scholarly works on genealogies (e. g. Leopold Genicot's), reaching a conclusion that dynastic history is a modern

10 "Based around the successions of the kings of France, and the best-known of all prose vernacular dynastic histories, this work met with remarkable success in the Later Middle Ages when it was copied for use in aristocratic households in spite of its relentlessly royalist perspective, perhaps contributing in a small way to a steady revival of royal power." WEST 2012, p. 503.

11 WEST 2012, p. 504.

12 SHOPKOW, Leah. Dynastic history. In MAUSKOPF DELIYANNIS, Deborah (ed.) Historiography in the Middle Ages. Leiden : Brill, 2003, pp. 217-248.

13 SHOPKOW 2003, p. 218. Cf. DUBY, Georges. Chivalrous Society. Berkeley ; Los Angeles : University of California Press, 1980.

14 SHOPKOW 2003, p. 218. Cf. GEARY, Patrick. Phantoms of Remembrance : Memory and Oblivion at the End of the First Millennium. Princeton : Princeton University Press, 1996. 
Table 1

The most important texts for dynastic history in the Middle Ages

Nennius Historia Britonum

Asser Life of Alfred the Great

Gesta Normannorum Ducum of William of Jumieges

Chroniques des comtes d'Anjou et des seigneurs d'Amboise

Relation de infoedatione comitatus Namucensis

Historia Welforum Weingartensis

Lamberti Ardensis historia comitum Ghisnensium

Österreichische Chronik von den 95 Herrschaften

Frutolf-Ekkehard (chronica regia)

Suger Vie de Louis VI le Gros, Louis VII

Grandes Chroniques de France

Compendium historie in genealogia Christi

Assises de Jerulasem term with no medieval counterpart, a category that brings together works that medieval people would have seen as related; she also mentions other forms of dynastic history, such as family trees (from the 12th century) and family necropolises from the 13th century onwards. Very debatable is her statement on Frutolf, when labelling his history as regnal, as

well as on his continuators Ekkehard and Kaiserchronik, saying that these "might be called dynastic, even though organized in annalistic form, in that the emperors are the main concern of the chronicle." In the end, Shopkow comes to the conclusions that "writing down accounts of the past organized around the descent of the family does not seem to have been a primary means for most families of creating family identity", and that many dynastic histories were junctions between a family and a domain (national character). ${ }^{15}$

Dynastic identity has been recently studied by Liesbeth Geevers and Mirella Marini, ${ }^{16}$ who broadened the time span of the creation of dynastic identities in Europe from the traditional period between the 10th and the 13 th century to a wider period reaching from the 10 th to the 18th century. They speak about

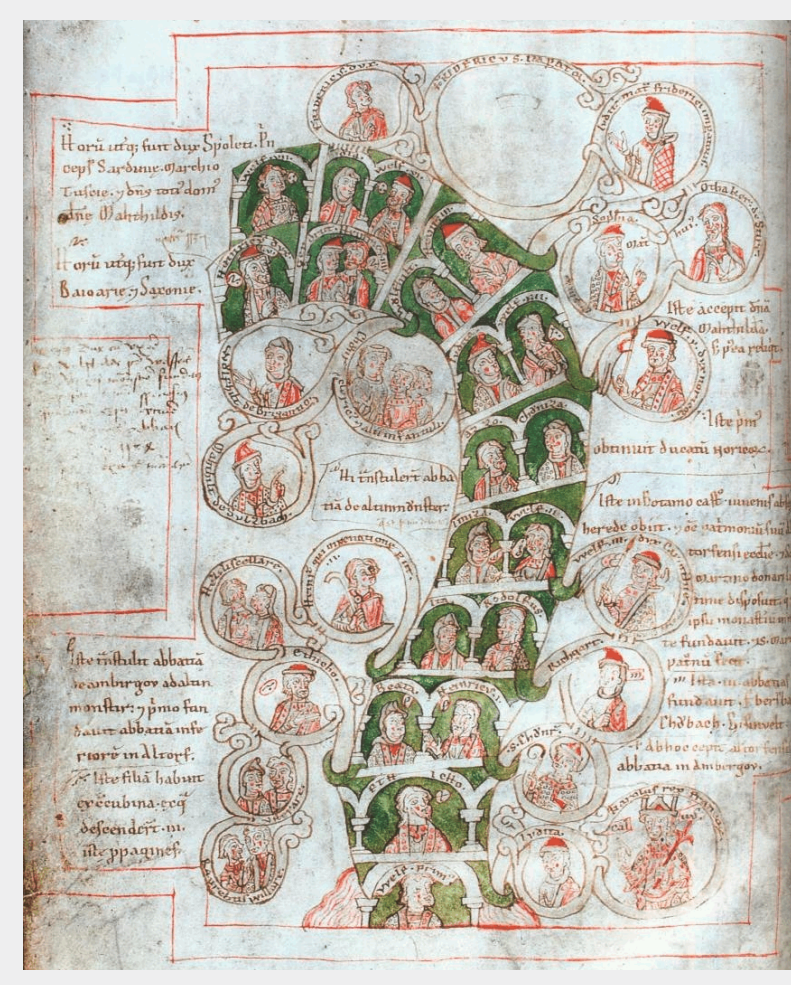
Figure 2: Genealogia Welforum. Hessische Landesbibliothek, Fulda, ms. D. 11 folio $13 v$. the construction

16 GEEVERS, Liesbeth - MARINI, Mirella. Aristocracy, Dynasty and Identity in Early Modern Europe. In GEEVERS, Liesbeth - MARINI, Mirella (eds.) Dynastic Identity in Early Modern World. Rulers, Aristocrats and the Formation of Identities. London : Ashgate, 2015, pp. 1-24. 
of identity in a dynastic context. Their concept is that dynasties are essentially groups of people. When people consider themselves a group, they invariably create an identity, based more often than not on a collective memory. A collective memory and sense of identity therefore imbued a noble family with shared interests: to uphold the dynasty's position. The constructed dynastic identity created shared interests and also served a normative purpose. Geevers and Marini perceive the concept of dynastic identity as a dynamic notion, constantly challenged and changeable so as to adapt to new contexts. To the essential question of what a dynasty is, they quote standard dictionary definitions, such as "a succession of people from the same family who play a prominent role in business, politics, or another field" and "a dynasty is, after all, a family."17 They stress the definition of Wolfgang Weber that a dynasty is, to a very large extent, a social construction, and shared identity - based on history, genealogy, patrimony and socialisation - is a central part of it. The conclusion states that: "whereas previously kinship relationships were considered to have developed from a broad group to smaller patrilineal groups with an enhanced awareness of their shared genealogy between 1000 and 1300 CE, more recent historiography situates this development in a much longer period stretching from the post Carolingian era into the seventeenth century - and really taking off between 1400 and $1700 .{ }^{\prime \prime 8}$

\section{Examples of Current Approaches}

\section{THE WELFS}

Beate Kellner showed how unique the genealogical traces of the Welfs were in the Middle Ages. ${ }^{19}$ Already from the first half of the 12 th century, they produced texts, pictures, monuments and other forms of Welf memoria in an unprecedented number and frequency. This amount was unattainable by other royal lineages like the Carolingians, Ottonians or Salians, or by their 12th-century counterparts or fierce opponents like the Capetians, Plantagenets, or Staufians. They were consciously forging their identity, fama of the past and hopes for the future. Although Kellner does not speak about dynasty, she uses similar terms like welfische Genealogien, Herrschaftsphasen der Geschlets, welfischen Herrschaft etc. ${ }^{20}$

The most famous example of an early text is the Genealogia Welforum ${ }^{21}$ from c. 1120 (preserved only in one codex in Weihenstephan), commissioned by Welf VI who is recorded in the text as Gwelfo noster. Curiously enough, their first ancestor was not a Welf, but a certain Eticho. The work stresses the imperial connections of the first Welfs (e. g. Eticho's daughter was married to Charles the Stammer). The first Welf (Gwelfum huius nominis primum) occurred only in the 4th generation. When tracing the etymology of the name Welf, the Genealogia

17 GEEVERS - MARINI 2015, p. 9.

18 GEEVERS - MARINI 2015, p. 13. For the earlier period see: HAMMER, Hans. Visions of Kinship in Medieval Europe. Oxford : Oxford University Press, 2018.

19 Next paragraph follows: KELLNER 2004, p. 297 f.

20 KELLNER 2004, p. 298.

21 Genealogia Welforum. In Monumenta Germaniae Historica (below MGH) : Scriptores in Folio XIII (below SS.) : Supplementa tomorum I - XII. WAITZ, Georg (ed.). Hannover : Imp. Bibliopolii Hahniani, 1881, pp. 733-734. 
proposes the example of the Latin catulus, which connects the Welfs with the famous Roman Catilina, claiming that the name was transferred sanguinis ratione in hanc prosapiam (i. e. the Welfs).

Another influential work was the famous Historia Welforum, ${ }^{22}$ written in AD 1170, which became the first chronicle from the German lands speaking uniquely about the history of a princely house (of South German provenience). The anonymous author studied old chronicles, history books and charters, but was not able to find any Welf ancestor before Count Gwelf, who lived at the time of Charlemagne. In the first chapter, he describes the perception of the House of Welfs and describes its organisation. The leading position was that of the Duke, then came the ministeriales (familia maior) and serfs (familia minor); subsequently, the work lists all the officers of the court. The author stresses that the Welf House was arranged in a royal manner (Domum quoque suam regio more ordinaverunt). Symptomatically, the terms domus, familia and curia repeatedly overlap throughout the work. ${ }^{23}$

\section{THE WITTELSBACHS}

French medievalist Jean-Marie Moeglin studied the dynastic self-consciousness and tensions between the imperial and the local interests of the German princely families of the Wittelsbachs, the Habsburgs and the Hohenzollerns in the Late Middle Ages. ${ }^{24}$ Moeglin concludes that the rise of the Habsburgs, Wittelsbachs and Hohenzollerns had a similar tone, as all three comital families were promoted to a ducal status by imperial grace.

Bavarian late medieval historiography tried to create an unbroken line of the Bavarian Dukes and presented all these rulers as Wittelsbachs, with the first attempts made in the 12 th and 13th centuries after their coming to power in 1180. The proposed genealogy traced the Bavarians to Armenia, with their legendary ancestor Bavorus. In the 13th century, the first sources on the Wittelsbachs were preserved in Hauskloster Scheyern. As for the Welfs, the links between the Wittelsbachs and the Emperors Arnulf and Charlemagne were emphasised. This continued in the 14 th and the 15 th century. The changes in 1180 were interpreted only as a continuation of the Bavarian imperial tradition (Fürstentafel von Scheyern). Strong emphasis on this can be felt in the Bavarian chronicles of Andreas von Regensburg, Veit Arnpeck, etc.

22 Historia Welforum Weingartensis. In MGH : SS. XXI. WEILAND, Ludewic (ed.). Hannover : Imp. Bibliopolii Hahniani, 1869, pp. 454-471.

23 KELLNER 2004, pp. 309-325. For more details, see: OEXLE, Otto Gerhard. Die "sächsische Welfenquelle" als Zeugnis der welfischen Hausüberlieferung. In Deutsches Archiv für Erforschung des Mittelalters, 1968, Vol. 24, No. 2, pp. 435-497; OEXLE, Otto Gerhard. Welfische Memoria. Zugleich ein Beitrag über adlige Hausüberlieferung und die Kriterien ihrer Erforschung. In SCHNEIDMÜLLER, Bernd (ed.) Die Welfen und ihr Braunschweiger Hof im hohen Mittelalter. Wiesbaden : Harrasowitz, 1995, pp. 61-94; BECHER, Matthias. Der Verfasser der >Historia Welforum` zwischen Heinrich dem Löwen und den süddeutschen Ministerialen des welfischen Hauses. In FRIED, Johannes - OEXLE, Otto Gerhard (ed.) Heinrich der Löwe. Herrschaft und Repräsentation. Konstanz : Thorbecke, 2003, pp. 347-380.

24 MOEGLIN, Jean-Marie. Dynastisches Bewusstsein und Geschichtsschreibung. Zum Verständnis der Wittelsbacher, Habsburger und Hohenzollern im Spätmittelalter. In Historische Zeitschrift, 1993, Vol. 256, No. 3, p. 593-635. 
To sum up, we can state that Bavarian identity was connected to the Wittelsbach dynasty and it became a dynastic, ducal identity. ${ }^{25}$ In this context, a wide range of synonyms was introduced. For example, Land stands for the fundamental connection between the Duke from the Wittelsbach dynasty and the people of the Land. Haus zu Bayern stressed the importance of the dynasty even more, as Haus was perceived as dynasty, although, in the 14th and the 15th century, the term Haus (in Bavaria and Austria) changed to signify the unity of the land and the people with all their rights, privileges and liberties. Consequently, all the Wittelsbach dukes were dukes of the House of Bavaria and their inhabitants lived in this house. In the same way, all the dukes had the same Wittelsbach blood (Blut von Bavaria). ${ }^{26}$

\section{THE HABSBURGS}

The Habsburgs, ruling in Austria for more than six centuries, became an embodiment and representative of the universal and supranational principle of monarchy. The concept of the ruling family of the house always stood at the centre of their political endeavours. ${ }^{27}$ Their rich genealogical mythology connected them not only to the noble German ruling houses, the Carolingians and the Merovingians in particular, but their descent could also be traced back to the Roman families of the Anicii and Iulii, the Trojans or even Noah and Ham. Before moving to Austria, the Habsburgs had their residence in the Habsburg castle in the present-day Swiss canton of Aargau, built in 1020. They founded religious centres that were supposed to keep their family's memory and history (Muri monastery) and quickly joined the party of imperial supporters, gaining access to the Salian and Later Staufian Emperors. ${ }^{28}$ In domestic policy, the principle of collective inheritance and investiture with total holdings - the right of all sons to inherit in common, in contrast to the principle of primogeniture - was maintained by the Habsburgs with notable stubbornness. At the same time, this divided and distributed - but took into account also the rights of inheritance of the whole House - the unified and maintained family property. In the person of Rudolf of Habsburg, regarded by later Habsburgs as their real ancestor, the dynasty obtained a notable and famous hero. By defeating Ottokar of Bohemia and acquiring the royal title, Rudolf laid the foundations for the future prosperity and power of the House of Austria, as the Habsburgs started to style themselves soon. Other denominations were gradually introduced: Herrschaft zu Oesterreich - referring to the political homeland

25 MOEGLIN, Jean-Marie 1993, p. 608.

26 The standard work on the Wittelsbach dynasty is: HOLZFURTNER, Ludwig. Die Wittelsbacher. Staat und Dynastie in acht Jahrhunderten. Stuttgart : Kohlhammer, 2005; see also: ZOTTMAYR, Franz Xaver. Genealogie des königlichen Hauses Baiern. Füssen : Jakob Winterhalter, 1834; HÄUTLE, Christian. Genealogie der erlauchten Stammhauses Wittelsbach. München : Manz, 1870; NIEHOFF, Franz (ed.). Das Goldene Jahrhundert der Reichen Herzöge. Landshut : Museen der Stadt Landshut, 2014.

27 KRIEGER, Karl-Friedrich. Die Habsburger im Mittelalter. Von Rudolf I. bis Friedrich III. Stuttgart : Kohlhammer, 2004, speaks about dynastische Machtpolitik, Königsdynastie, Hauspolitik, domus Austriae, die Krise der Dynastie, formierung zur europäischen Grossdynastie etc. This book traces the rise of the ruling dynasty, the formation of a European Large dynasty (Grossdynastie), the function and importance of the Habsburg family as a Royal dynasty, the self-consciousness of the Habsburg dynasty etc.

28 STERCKEN, Martina. Shaping a Dominion : Habsburg Beginnings. In LOUD, Graham A. - SCHENK, Joachen (eds.) The Origins of the German Principalities. London ; New York : Routledge, 2017, p. 335. 
of the dynasty in the regions of the Danube and the Southeast Alps and Tyrol; Communitas Austriaca - started by the Babenbergs and developed by the Habsburgs; from 1283, the idea of communitas terrarium, formed by Austria, Styria and Krain, and later, in the 15th and 16th century, domus Austriae (Haus Osterreich). In 1338, after the acquisition of Carinthia and its equalisation with Austria and Styria, Duke (Herzog) Albrecht II proclaimed the doctrine of unus populus, unum dominium, una gens, which was later extended to other acquired lands and became a maxim of the Habsburgs of the communitas Austriaca as a state unit. ${ }^{29}$

The Habsburgs came to Austria as foreigners (Alamans or Swabians) and identified themselves with the dominium Austriae only later. Their dynasty thus became the domus Austriae and this resulted in the need to have a list of its rulers created, so the famous Chronik von den 95 Herrschaften was written by von Leopold von Wien. This work lists 81 invented rulers, dating from the first Austrian Landesherr Abraham von Tremonaria, who came to the land bey der Tunaw 859 years after the Flood. ${ }^{30}$

Previous scholarship repeatedly stressed the importance of the late 13th and early 14th century when the Habsburgs acquired a royal status and, unlike the neighbouring dynasties, continued to rule for many centuries to come. ${ }^{31}$ Another decisive phase came in the 15 th and early 16 th century, when a functional system of marriage connections and inheritance treaties gave the dynasty one ruling title after another, without having to fight for it much. As a matter of fact, the Habsburgs came

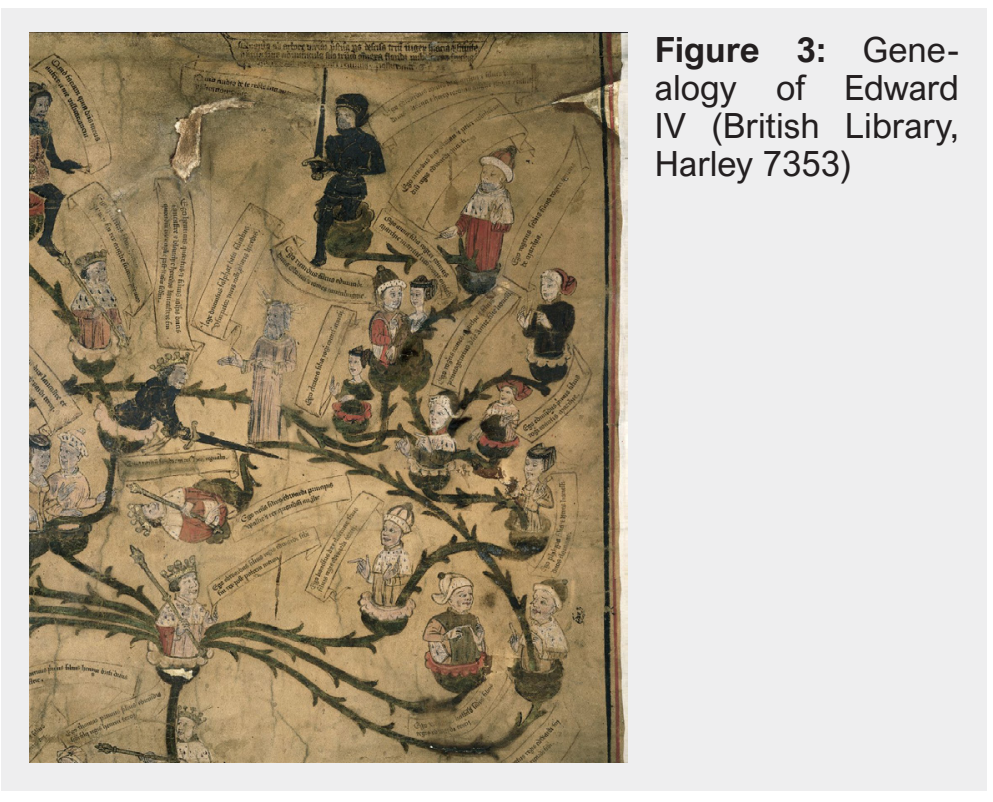
to be internationally recognized only between 1477 and 1526. It is no wonder that it was the main architect of this policy, Emperor Maximilian I, who occupied himself with genealogical theories and legends more than any other Habsburg ruler. The Habsburgs were seen as Hector's descendants and, as they were related by blood to almost all the ruling houses in Europe, they made claims to these respective territories. ${ }^{32}$

29 WANDRUSZKA, Adam. Das Haus Habsburg : Die Geschichte einer europäischen Dynastie. Stuttgart : Friedrich Vorwerk Verlag, 1956; HÖDL, Günther. Habsburg und Österreich 1273 - 1493. Wien ; Köln ; Graz : Böhlau, 1988; WELTIN, Maximilian. Das Land und sein Recht. Ausgewählte Beiträge zur Verfassungsgeschichte Österreichs im Mittelalter. REICHERT, Folker - STELZER, Winfried Stelzer (eds.). Wien ; München : R. Oldenbourg Verlag, 2006; Die Länder und das Reich. Der Ostaalpenraum im Hochmittelalter. Österreichische Geschichte im Hochmittealter 1122 - 1278. WOLFRAM, Herwig (ed.). Vienna : Ueberreuter, 2003.

30 Österreichische Chronik von den 95 Herrschaften. In MGH : Deutsche Chroniken 6 (below Dt. Chron.). SEEMÜLLER, Joseph (ed.). Hannover ; Leipzig : Hannsche Buchhandlung, 1909, pp. 1-224.

31 STERCKEN 2017, p. 329.

32 WANDRUSZKA 1956; LACKNER, Christian. Das Haus Österreich und seine Länder im Spätmittelalter. Dynastische Integration und regionale Identitäten. In MALECZEK, Werner (ed.) Fragen der politischen 


\section{Central Europe (Hungary, Poland and Bohemia)}

Polish medievalist Zbigniew Dalewski has recently published essential articles on the patterns of dynastic identity, dynastic power as family business, and dynastic conflict. ${ }^{33}$ He concluded that "there is no doubt about dynastic nature of power in Poland, Bohemia, and Hungary in the earlier Middle Ages, ...even though there is still much controversy about some essential aspects of practice of dynastic rulership, and especially patterns of succession to the throne. ${ }^{134}$ For Dalewski, the main idea is the relation between the perception of rule and monarchic power as a given, accessible to and shared by a wide ruling family in a horizontal sense (as defined by the Carolingians), or the concept of a single vertical ruling family with access to rulership limited to the close line and inherited from father to son. In the West, the essential change came when the Carolingians were replaced by new dynasties - by the Ottonians (Saxonians) in the East Frankish realm in 929, and by the Capetians in the western parts. Henry I yielded power straight to his son Otto, who outdid the other members of the family. A new dynasty, built by Henry, was thus designed as restricted to a single line of the royal family, with the majority of his relatives, including most of his sons, remaining outside it. ${ }^{35}$

As a consequence, the Ottonian dynasty did not follow the patterns set by the Carolingians. They created their dynastic identity in a narrower, vertically oriented pattern and focused on one single representative in each generation. In this respect, the Ottonians refused the traditional Carolingian vertical sense of dynasty and respective distribution of power. Usually, the Carolingians did not restrict the right to throne succession to only one of their sons, but allowed every male descendant, at least theoretically, to hope for their share in power. This ended definitively in 954 when the West-Frankish Kingdom quit the old practice of handing over the crown to all their sons. In doing so, they probably followed the newly established Ottonian pattern.

Dalewski provides a comparative study of the Rurikid, the Arpadian and the Piast attempts to change the rule from the wide family to a close vertical line of successive rulers from father to son (Vladimir, Stephen, Mieszko / Boleslav). In all three cases, this did not prove to be successful immediately, as the side lines of the ruling dynasty also claimed their share in the power and right to rule. In Central and Eastern Europe, "the ruling houses - similarly to the aristocratic families - ought to be perceived not just as (or, not only as) blood-ties-based communities but rather, as political constructs. ${ }^{136}$ Dalewski draws further conclusions from the examina-

Integration im mittelalterlichen Europa. Ostfildern : Thorbecke, 2005, p. 273-301; LHOTSKY, Alphons. Geschichte Österreichs seit der Mitte des 13. Jahrhundert (1281 - 1358). Vienna : Böhlau, 1967.

33 DALEWSKI, Zbigniew. Family Business : Dynastic Power in Central Europe in the Earlier Middle Ages. In Viator: Medieval and Renaissance Studies, 2015, Vol. 46, No. 1, pp. 43-60; DALEWSKI, Zbigniew. "Patterns of Dynastic Identity in the Early Middle Ages." In Acta Poloniae Historica, 2013, Vol. 107, No. 1, pp. 5-43; DALEWSKI, Zbigniew. Ritual and Politics : Writing the History of a Dynastic Conflict in Medieval Poland. Leiden : Brill 2008.

34 DALEWSKI 2015, p. 43.

35 DALEWSKI 2013, p. 6.

36 DALEWSKI 2013, p. 26. 
tion of three case studies: Theodoric and Mieszko II of Poland, 1032, Vladivoj and Boleslav III of Bohemia, 1002, and Stephen I and Koppány of Hungary, 997.

One of his main arguments is that there was a generally accepted belief among the representatives of the Central European dynasties in the communal nature of monarchical power. All the members of the ruling family were supposed to have an equal right to this power. Monarchical power was therefore regarded as belonging to the entire ruling family, under-

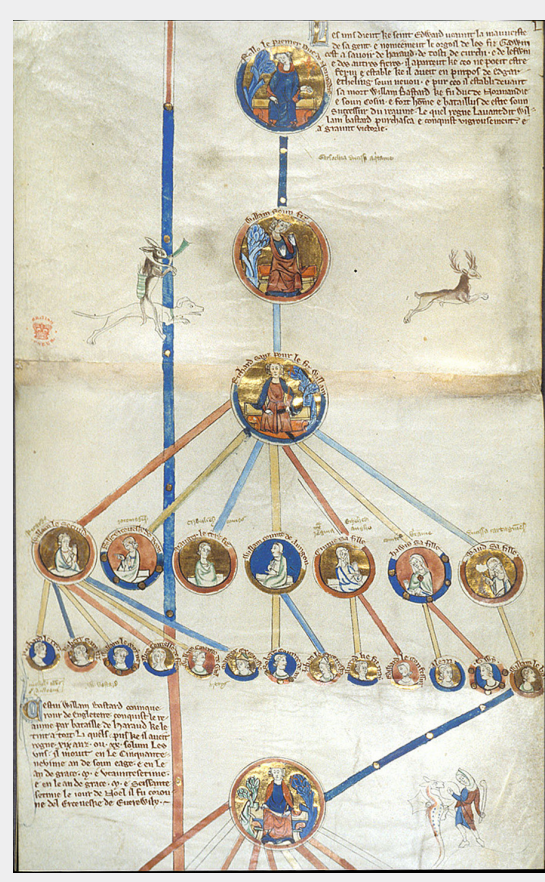
Figure 4: Royal 14 B V Membrane 4 and 5 Rollo and his descendants stood as a large kin group, including on equal terms a variety of close and more distant individual relatives, or lineages. That is why Dalewski speaks about the notion among the Piasts, the Přemyslids and the Arpadians as a sort of "family business," in which all the members of the family held equal shares and participated equally. Essential changes in the perception and exercise of power by the dynasties of Central Europe happened at the end of the 13th century (in Poland only in the 14th century). This was due to the important social and political changes of the period that enabled the definitive adoption of the father-to-son system of succession. ${ }^{37}$

\section{Conclusion}

The dynastic perception of the ruling families usually occurred either in the horizontal sense (all relatives with equal right to rule) or in the vertical sense (access to power limited to the close nuclear family of the ruler and his direct descendants, i.e. his sons, or only his eldest son).

The main change took place presumably in the 10th century, after the fall of the Carolingians, who were replaced by the Ottonian and the Capetian dynasties. With this as a starting point, current medieval studies therefore apply the notions of dynastic history, dynastic historical writing, dynastic chronology etc., in a very broad, and usually not specifically defined, manner. Calling for a strict banishment of the very

37 The topic is currently under close examination by scholars within the region. FONT, Márta. Dinasztia, hatalom, egyház. Régiók formálódása Európa közepén 900 - 1453. Pécs : n. p., 2009; FONT, Márta. Dynastic Tradition and the Legitimation of Power. In Canadian-American Slavic Studies, 2015, Vol. 49, No. 4, pp. 407-420; BAGI, Dániel. Genealogische Beziehungen zwischen Piasten und Arpaden im 11. und frühen 12. Jh., In ADAMCZYK, Dariusz KERSKEN, Norbert (eds.) Fernhändler, Dynasten, Kleriker. Wiessbaden : Harrasowitz, 2015, pp. 135-154; BAGI, Dániel. Genealogical Fictions and Chronicle Writing in Central East Europe in the 11th - 13th Centuries. In PLESZCZYNSKI, Andrzej et al. (eds.) Imagined Communities. Constructing Collective Identities in Medieval Europe (d’alej Imagined Communities). Leiden : Brill, 2018, pp. 15-29; DALEWSKI, Zbigniew. Modele władzy dynastycznej w Europie Środkowo-Wschodniej we wcześniejszym średniowieczu. Warszawa : PAN, 2014; DALEWSKI, Zbigniew. Strategies of Creating Dynastic Identity in Central Europe in the 10th - 11th Centuries. In Imagined Communities, pp. 30-45. I will deal with these issues in a separate contribution. 
concept of dynasty as such would not be an adequate reaction to this state of the art. It is much more beneficial to point out the great diversity, versatility and semantic richness inherent in this concept. There is no single ideal type of dynasty in history, not even in the period traditionally called the Middle Ages. ${ }^{38}$ Future research may propose a new look at the historical phenomenon most of us perceive as a clear and given fact. Medieval dynasties are defined as based on family, kinship and shared tradition. In fact, they should not be seen only as a biological line of relatives, but, more importantly, as a political construct. Last, but by no means least, dynasty should always be scrutinized in connection with genealogy, idoneity and legitimacy. ${ }^{39}$

The lack of interest by modern scholars in defining dynasty in the Middle Ages may also be influenced by another fact. They can easily build on the definition proposed by the late fourteenth-/early fifteenth-century Tunisian Arab historian Ibn Khaldun $(1332-1406)$ in his Introduction to History:

"One cannot imagine a dynasty without civilization, while a civilization without dynasty and royal authority is impossible, because human beings must by nature co-operate, and that calls for a restraining influence. Political leadership, based either on religious or royal authority, is obligatory as (such a restraining influence). This is what is meant by dynasty." ${ }^{\prime \prime 0}$

38 The most complex theoretical assessment has been recently proposed by: DUINDAM, Jeroen. Dynasties. A Global History of Power 1300 - 1800. Cambridge : CUP, 2015; DUINDAM, Jeroen. Dynasties. In Medieval Worlds. Comparative and Interdisciplinary Studies, 2015, Vol 2, No. 1, pp. 59-78.

39 See most recently: ANDENNA - MELVILLE 2015.

40 KHALDÛN, Ibn. The Muqaddimah : An Introduction to History. ROSENTHAL, Franz (trans.). Princeton ; New York : Princeton University Press, 1958, Book IV, Chap. 19, p. 472.

Cituj:

ZUPKA, Dušan. Medieval Dynasties in Medieval Studies: A Historiographic Contribution. In Forum Historiae, 2019, roč. 13, č. 2, s. 89-101. ISSN 1337-6861. DOI: https://doi.org/10.31577/forhist.2019.13.2.6

Mgr. Dušan Zupka, PhD.

Oddelenie stredovekých dejín

Historický ústav SAV,

P.O.Box 198, Klemensova 19

81499 Bratislava

Slovenská republika

dusan.zupka@savba.sk

Katedra všeobecných dejín

Filozofická fakulta Univerzity Komenského

Gondova 2, P.O.Box 32

81499 Bratislava

Slovenská republika

dusan.zupka@uniba.sk 